\title{
Challenges and Opportunities for Human Resource Management in Indonesian Dairy Farms
}

\author{
Ely Estiningtyas, Abdul Malik
}

(STIE Jaya Negara Tamansiswa Malang)

\begin{abstract}
This study aims to examine the development of dairy farming in Indonesia by using the online interview method as a method of data collection, which is then quantified based on the results of the interview. We conducted online interviews with 120 cattle breeders in Indonesia by random sampling and then quantified them for analysis using the narrative quantitative method with the ordinary least square model to perform data regression. This research focuses on looking at the growth of the dairy business which is reflected in the monthly average farmer income calculated from 2000 to 2019, the number of cows, the number of employees and the welfare of employees. We find that the development of the dairy business is influenced by the number of dairy cows, the number of employees and the welfare of the employees which is a reflection of the level of employee job satisfaction.
\end{abstract}

Keywords : Dairy Cows, Livestock, Employees

\section{Background}

Dairy farming in Indonesia has grown (Experts,2020), from family-based businesses to group businesses helping cooperatives such as the Bogor milk production cooperative, the South Bandung Pangalengan Animal Husbandry Cooperative and others. To meet the domestic demand for milk in Indonesia, of course, requires a lot of breeders and there needs to be an organization that manages it with various forms of organization. Generally, milk management organizations in Indonesia are cooperatives (Park \& Haenlein,2013). Successful dairy farming tends to grow and the number of dairy cows it raises continues (Flanders \& Gillespie,2015). This of course requires an increasing number of workers and needs to be managed properly. When the cattle farm develops and manages more dairy cows, the management of human resources will also become more complex (Mutinda et al,2015). Cooperatives in Indonesia, from cooperatives in West Java to cooperatives in East Java, based on the author's observations, tend to manage the final product to be marketed, namely milk. However, the management of dairy cows is managed by members who are cattle breeders. This is good enough to ensure that the final product of the farmer, namely milk, can be managed quickly and marketed properly. However, there is another thing that needs to be understood, namely the business development of dairy farmers, which is likely to continue to grow and produce more milk. Cooperatives must increase their milk capacity and require large investments and need to be borne by cooperative members. However, when there is a disparity in cattle management, of course, this becomes a challenge. 
Another challenge is also in the field of livestock welfare management. The low level of livestock welfare certainly affects the quantity and quality of milk produced (Makkar,2013). When more and more cows are managed, it requires additional farmland and pens and feed. Adding land and stables also requires a lot of investment. The desire of breeders who increasingly want to develop collides with the need for capital and an increase in the price of livestock land. The growing livestock situation also has the risk of having an impact on the stress level of farmers and potentially impacting the mental health of breeders (Halachmi,2015). This research tries to present a quantitative narrative from the point of view of cattle breeders by conducting interviews with 120 dairy farmers who have experienced good development or addition of livestock. We try to analyze the number of livestock, the stress level of farmers, the number of workers or pen children, the welfare of workers or pen children, the income of farmers.

\section{Literature Review}

The welfare of dairy cows is very important to produce quality milk. Because the level of cow stress will affect the amount of milk and milk quality (Rushen et al,2007). Training for livestock and livestock workers is very important to improve the management of dairy cows so that they are able to maintain cow stress levels to maintain cow milk production in Indonesia. Employees are an important asset in a dairy farm because employees or workers manage and operate a dairy business (Indiresan,2003). Especially when livestock is growing rapidly. The quality of the workforce on a dairy farm greatly affects the success rate of the dairy business. The challenge for farmers is recruitment and training. Employee training is very important in the dairy farming business. Dairy cow employees must understand the task and have sufficient skills to carry out the task. Dairy cow employees must understand the handling and management of dairy cows properly. So that technical and operational training must be obtained by employees of dairy entrepreneurs (Moran \& Chamberlain,2017). Another important factor is that the organizational structure of the dairy business must also be clear so that there is a clear capital structure. So that a clear division of duties and supervision and responsibility is formed.The organizational structure is also related to the distribution of wages and welfare according to the level of contribution to the company. Good milk business management can increase the success of the dairy business.

\section{Reserach Method}

Collecting data in this study using interviews with 120 cattle breeders in Indonesia using random sampling. The interview aims to extract data in the form of the number of dairy cows owned by the farmer, the farmer's stress level, the number of workers, the welfare of the workers, and the farmer's income. We use total data or all the data obtained is summed based on the group of variables determined based on literature review and background, after which regression is performed using the ordinary least squares (OLS) method with the following equation:

$\mathrm{Fi}_{\mathrm{t}}=\mathrm{C}_{\mathrm{t}}+\beta_{1} \mathrm{Nd}_{\mathrm{t} 1}+\beta_{2} \mathrm{Nw}_{2}+\beta_{3} \mathrm{Ww}_{\mathrm{t} 3}+\mathrm{e}_{\mathrm{t}}$

Where,

$\mathrm{Fi}=$ Farmer's income

$\mathrm{Nd}=$ Number of Dairy Cows

$\mathrm{Nw}=$ Number of Workers 
$\mathrm{WW}=$ Welfare of the workers

$\mathrm{e}=$ Error Term

\section{Result and Discussion}

The estimation results are as follows:

$\mathrm{FI}=-67040083.4533+2572273.38696 * \mathrm{ND}+11449367.5918 * \mathrm{NW}+10.1967714032 * \mathrm{WW}$

From the OLS estimation, the farmer's income is influenced by the number of dairy cows, the number of workers and the job satisfaction of the employees as reflected by the welfare of the farm employees. Where every $1 \%$ increase in farmer's income is followed by an increase in employee welfare by $10 \%$. Where the level of job satisfaction and employee quality greatly affects the income of the breeders plus the number of dairy cows and the number of farm employees which are briefly described in Table 1 illustrates the estimation results as follows:

Table 1. Estimation Results

\begin{tabular}{|c|c|c|c|c|}
\hline Variable & Coefficient & Std. Error & t-Statistic & Prob. \\
\hline $\mathrm{C}$ & -67040083 & 31699047 & -2.114893 & 0.0505 \\
\hline ND & 2572273 & 1334262 & 1.927863 & 0.0718 \\
\hline NW & 11449368 & 3351666 & 3.416023 & 0.0035 \\
\hline WW & 10.19677 & 4.238306 & 2.40586 & 0.0286 \\
\hline R-squared & 0.8911 & \multicolumn{2}{|c|}{ Mean dependent var } & $1.61 \mathrm{E}+08$ \\
\hline Adjusted R-squared & 0.870681 & \multicolumn{2}{|c|}{ S.D. dependent var } & 64697178 \\
\hline S.E. of regression & 23265729 & \multicolumn{2}{|c|}{ Akaike info criterion } & 36.93972 \\
\hline Sum squared resid & $8.66 \mathrm{E}+15$ & \multicolumn{2}{|c|}{ Schwarz criterion } & 37.13886 \\
\hline Log likelihood & -365.3972 & \multicolumn{2}{|c|}{ Hannan-Quinn criter. } & 36.97859 \\
\hline F-statistic & 43.64113 & \multicolumn{2}{|c|}{ Durbin-Watson stat } & 1.244223 \\
\hline Prob(F-statistic) & \multicolumn{4}{|l|}{0} \\
\hline
\end{tabular}

Based on the estimation results described in Table 1.This shows that the development of the number of dairy cows, the number of employees and the job satisfaction of employees is positively related to the farmer's income, so that land challenges and recruitment of quality employees must be anticipated by setting aside income for land and human capital investment including recruitment costs new hires and employee turnover costs. Based on the estimation, it can be estimated that the average farmer income growth per month from 2000 to 2019 is in Figure 1 as follows:

Figure 1. Forecasting results of monthly average farmer income
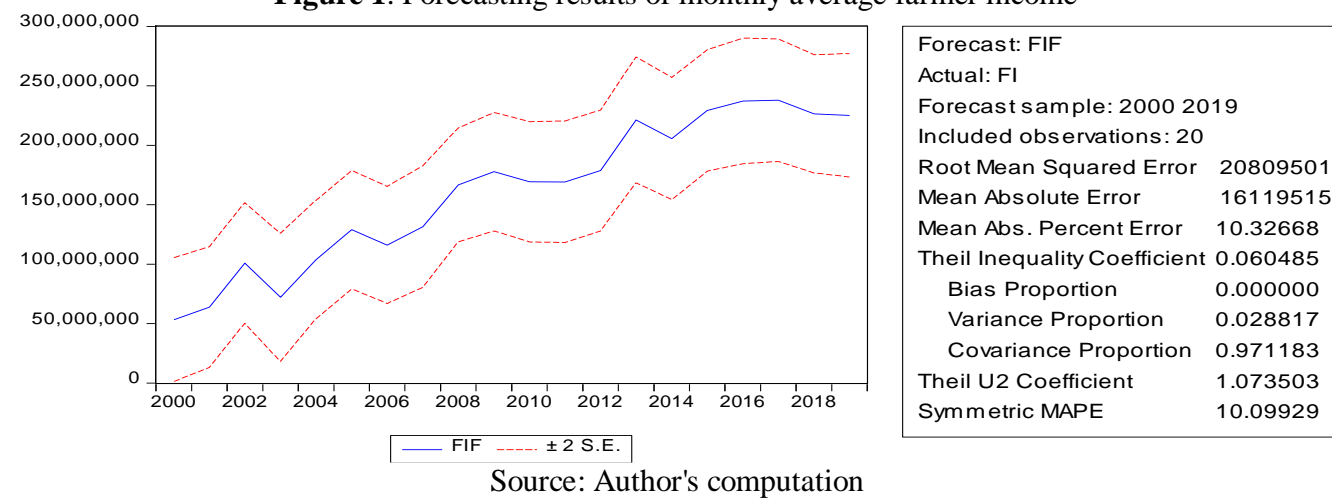

Source: Author's computation 
Based on the forcasting results in Figure 1, the development of dairy farms in Indonesia tends to increase during the study period which is reflected in the results of the average monthly income of each farmer who is the research sample.

\section{Conclusion}

Dairy farming in Indonesia tends to develop from year to year. However, the development of the cattle business is always followed by an increase in the number of dairy cows being raised and additional employees so that it must be followed by additional land for the needs of cow care, stables, green land and employee housing. is a challenge in addition to the challenge of providing quality employees.

\section{Reference:}

Experts,A.(2020).General Knowledge 2020.New Delhi : Arihant Publication

Flanders,F., Gillespie,J.R.(2015). Modern Livestock\& Poultry Production. New York: Cengage Learning

Halachmi,I.(2015).Precision livestock farming applications.Wageningen : Wageningen Academic Publishers

Indiresan,P.V.(2003).Vision 2020: What India Can Be, and how to Make that Happen. Hyderabad : ICFAI Books

Makkar,H.P.S.(2013).Enhancing Animal Welfare and Farmer Income Through Strategic Animal Feeding: Some Case Studies. Washington,D.C : United Nations

Moran,J., Chamberlain,P).2017.(Blueprints for Tropical Dairy Farming: Increasing Domestic Milk Production in Developing Country.Clayton South : Csiro Publishing

Mutinda,G., Baltenweck,I., Omondi,I.(2015).Setting up sustainable dairy business hubs: A resource book for facilitators.Addis Ababa : ILRI

Park,Y.W., Haenlein,G.F.W.(2013).Milk and Dairy Products in Human Nutrition: Production, Composition and Health. Hoboken : John Wiley and Sons

Rushen,J., Passillé,A.M.D. ,Keyserlingk,M.A.G. (2007).The Welfare of Cattle. Cham : Springer 